\title{
Daunorubicin
}

\section{Results in Childhood Leukaemia}

\author{
RAE N. MATTHEWS and JOHN H. COLEBATCH* \\ From the Department of Haematology and Research Foundation, Royal Children's Hospital, Melbourne, \\ and Anti-Cancer Council of Victoria, Australia
}

Matthews, R. N., and Colebatch, J. H. (1972). Archives of Disease in Childhood, 47, 272. Daunorubicin: results in childhood leukaemia. Fifty children with acute leukaemia (44 lymphatic, 6 myeloid) were treated with daunorubicin. In 3 cases, it was given in courses of daily injections; in 47, single injections were given at 7- to 14-day intervals. On the latter (intermittent) regimen, in combination with prednisolone, a good response-complete, bone marrow, or clinical remission-occurred in 22 of 27 cases ( $81 \%$ ) of 'new' or previously untreated acute lymphoblastic leukaemia but in only 3 of 13 cases previously treated with other drugs. With acute myeloid leukaemia a good response occurred only when daunorubicin was given in combination with other cytotoxic drugs. The major side-effect was bone marrow depression with the related complications of haemorrhage and infection. Cardiotoxicity was not a problem; the cumulative total dose of daunorubicin did not exceed $26.8 \mathrm{mg} / \mathrm{kg}$. This study indicates that intermittent dosage with $2-3 \mathrm{mg} / \mathrm{kg}$ at intervals of 7 to 14 days is as effective as, and no more toxic than, the courses of daily injections that have been commonly used.

Daunorubicin (DRB) is now the approved name for the 2 apparently identical antibiotic substances originally described as daunomycin and rubidomycin. Its identification and chemical formula, its mode of action, and its experimental pharmacology were described in the 60 's by various workers. DRB forms a complex with DNA, it has marked antitumour activity and is highly toxic; in these respects it resembles dactinomycin, but differs in other ways.

In man, DRB has been used in a variety of neoplastic conditions. Remission has been reported in acute leukaemia, both lymphoblastic and myeloid (Jacquillat et al., 1966; Tan and Tasaka, 1966; Bernard et al., 1967, 1970; Hardisty and Norman, 1967; Holland, 1967, 1968). Regression of certain solid tumours has also been produced, e.g. of metastatic neuroblastoma, reticulum cell sarcoma, and rhabdomyosarcoma (Tan and Tasaka, 1966; Tan et al., 1967).

Toxicity has resulted from virtually all regimens of DRB used clinically. Bone marrow damage has been the most common toxic effect (Jacquillat

\footnotetext{
Received 16 September 1971.

$\star$ W. J. Kilpatrick Research Fellow of Anti-Cancer Council of Victoria.
}

et al., 1966; Tan and Tasaka, 1966). A syndrome of cardiorespiratory failure developed in some patients whose total dose of DRB exceeded 25 $\mathrm{mg} / \mathrm{kg}$, and this has been thought to be due to toxic effects on the myocardium (Jacquillat et al., 1966; Macrez et al., 1967).

Insufficient work has been reported to date to give a clear picture of the place of this potentially valuable but highly toxic drug in the treatment of leukaemia and solid tumours in childhood. Nor does the literature reveal whether other regimens may be superior to repeated courses of daily injections for 3 to 5 days, as has been commonly used in trials reported to date. Accordingly, pilot studies carried out in 1966-68 are described in this paper with data which suggest that a single injection every 7 to 14 days is as effective as the repeated courses of daily injections.

\section{Subjects and Methods}

Between April 1966 and October 1968, DRB was used in the treatment of 50 children aged 1 to 15 years at the Royal Children's Hospital, Melbourne. These children had acute leukaemia, which was lymphoblastic in 44 , myeloid in 6 . 17 had been treated previously with other drugs, but were in relapse when DRB was started 
('treated cases'), and 33 received DRB as their initial induction therapy, together with prednisolone for at least 10 days ('new cases'). The distribution of these cases by age, sex, and type and stage of leukaemia is shown in Table I.

\section{TABLE I}

Acute Leukaemia-Distribution of 50 Cases by Age, Sex, Type, and Stage of Disease

\begin{tabular}{l|c|c|c|c}
\hline & Age (yr) & \multicolumn{2}{|c|}{ Sex } & Total \\
\cline { 2 - 3 } \begin{tabular}{l|c|c} 
New cases \\
Lymphoblastic
\end{tabular} & $\begin{array}{c}1-11 \\
\text { Male }\end{array}$ & Female & 17 & 28 \\
Myeloid & $\begin{array}{c}\text { 2-15 } \\
\text { (median 10) }\end{array}$ & 3 & 2 & 5 \\
\hline $\begin{array}{l}\text { Treated cases } \\
\text { Lymphoblastic }\end{array}$ & $\begin{array}{c}1-14 \\
\text { (median 7) } \\
5\end{array}$ & 12 & 4 & 16 \\
Myeloid & 1 & 0 & 1 \\
\hline Total & 27 & 23 & 50 \\
\hline
\end{tabular}

Regimens and dosages were deliberately varied in the earlier pilot studies. The first 3 children were given a daily dose of $1 \mathrm{mg} / \mathrm{kg}$ intravenously for 3 to 5 days, following the pattern used in animal experiments and in early clinical trials by other workers (Table II, Group I). A further course was given 10 to 16 days after the end of the first course unless contraindicated by the peripheral blood picture.

In 1967, a regimen of intermittent therapy with single high-dose intravenous injections was introduced. It was planned to give these injections once weekly.
In practice, however, the intervals between them ranged from 7 to 14 days, the factors determining the exact length being the response of the disease and the degree of toxicity, as indicated by the peripheral blood (and sometimes bone marrow) pictures. The dose of each DRB injection varied from 2 to $3 \mathrm{mg} / \mathrm{kg}$. In some earlier cases (Group II) the dose was $2 \mathrm{mg} / \mathrm{kg}$; in 2 cases (Group IV) high doses of $3 \mathrm{mg} / \mathrm{kg}$ were tried; in the majority of cases (Group III), the starting dose was $2.5 \mathrm{mg} / \mathrm{kg}$ though it was commonly advisable to reduce the later doses to nearer $2 \mathrm{mg} / \mathrm{kg}$.

In all cases prednisolone $50 \mathrm{mg} / \mathrm{m}^{2}$ per day was given by mouth for at least 10 days concurrently with the DRB course, but the prednisolone had usually been discontinued some time before a remission was established. In 5 cases (Group V), DRB was given in combination with either one or two other cytotoxic agents administered concurrently, e.g. vincristine, cyclophosphamide, 6-mercaptopurine, and cytosine arabinoside. In these cases lower doses of DRB were used, ranging from 1.5 to $2.0 \mathrm{mg} / \mathrm{kg}$ per injection.

With the object of avoiding the serious cardiorespiratory complications reported by other workers, the total amount of DRB given to any child was not to be greater than $25 \mathrm{mg} / \mathrm{kg}$. In fact one child received a total of $26.8 \mathrm{mg} / \mathrm{kg}$ over a period of 19 weeks, but in the other cases the total given ranged from $2 \cdot 0$ to $24 \mathrm{mg} / \mathrm{kg}$.

\section{Results}

Tabulation. Results have been tabulated in relation to the dosage and regimen of DRB in Table III. The results in relation to the cytological type and the stage of the leukaemia have been recorded in Table IV for Groups II, III, and IV, where similar regimens were used. Groups I

TABLE II

Dosage Regimens in Relation to Type and Stage of Leukaemia (50 cases)

\begin{tabular}{|c|c|c|c|c|}
\hline & \multicolumn{2}{|c|}{ 'New' Cases } & \multicolumn{2}{|c|}{ Treated Cases } \\
\hline & $\begin{array}{c}\text { Acute } \\
\text { Lymphoblastic } \\
\text { Leukaemia }\end{array}$ & $\begin{array}{c}\text { Acute } \\
\text { Myeloid } \\
\text { Leukaemia }\end{array}$ & $\begin{array}{c}\text { Acute } \\
\text { Lymphoblastic } \\
\text { Leukaemia }\end{array}$ & $\begin{array}{c}\text { Acute } \\
\text { Myeloid } \\
\text { Leukaemia }\end{array}$ \\
\hline $\begin{array}{l}\text { Group I ( } 3 \text { cases }) \\
1 \mathrm{mg} / \mathrm{kg} \text { per day } \times 3-5 \text { days, repeated after interval of } 10-16 \text { days }\end{array}$ & 0 & 0 & 2 & 1 \\
\hline $\begin{array}{l}\text { Group II (11 cases) } \\
\quad 2 \mathrm{mg} / \mathrm{kg} \text { at weekly intervals }\end{array}$ & 5 & 1 & 5 & 0 \\
\hline $\begin{array}{l}\text { Group III (29 cases) } \\
\quad 2.5 \mathrm{mg} / \mathrm{kg} \text { at weekly intervals }\end{array}$ & 20 & 1 & 8 & 0 \\
\hline $\begin{array}{l}\text { Group IV ( } 2 \text { cases) } \\
\quad 3 \mathrm{mg} / \mathrm{kg} \text { at weekly intervals }\end{array}$ & 2 & 0 & 0 & 0 \\
\hline $\begin{array}{l}\text { Group } V(5 \text { cases }) \\
\quad \text { Combination therapy with VCR and } 6 \mathrm{MP} \text { or CSA }\end{array}$ & 1 & 3 & 1 & 0 \\
\hline Total & 28 & 5 & 16 & 1 \\
\hline
\end{tabular}


TABLE III

Results in Relation to Dosage Regimens (50 cases)

\begin{tabular}{|c|c|c|c|c|c|c|}
\hline Dosage Regimen* & $\begin{array}{l}\text { Complete } \\
\text { Remission }\end{array}$ & $\begin{array}{c}\text { Bone Marrow } \\
\text { Remission }\end{array}$ & $\begin{array}{c}\text { Clinical } \\
\text { Remission }\end{array}$ & $\begin{array}{c}\text { Partial } \\
\text { Remission }\end{array}$ & $\begin{array}{c}\text { No } \\
\text { Remission }\end{array}$ & Total \\
\hline Group I & 0 & 0 & $\frac{1}{(4) \dagger}$ & 0 & $\begin{array}{c}2 \\
(3-12)\end{array}$ & 3 \\
\hline Group II & $\begin{array}{c}1 \\
(8 \cdot 5)\end{array}$ & 0 & $(9 \cdot 6-12)$ & $\begin{array}{c}3 \\
(10 \cdot 3-23 \cdot 5)\end{array}$ & $\begin{array}{c}4 \\
(2-24)\end{array}$ & 11 \\
\hline Group III & $\begin{array}{c}15 \\
(4 \cdot 5-24 \cdot 3) \\
\text { median } 5\end{array}$ & $\stackrel{2}{2}(12 \cdot 5-26 \cdot 8)$ & $\stackrel{3}{(4 \cdot 5-9 \cdot 5)}$ & $\begin{array}{c}3 \\
(7-11 \cdot 7)\end{array}$ & $\begin{array}{c}6 \\
(2 \cdot 5-12 \cdot 5) \\
\text { median } 8\end{array}$ & 29 \\
\hline Group IV & 0 & 0 & $\begin{array}{c}1 \\
(11)\end{array}$ & $\begin{array}{c}1 \\
(10.5)\end{array}$ & 0 & 2 \\
\hline Group V & $\begin{array}{c}1 \\
(4 \cdot 2)\end{array}$ & 0 & 0 & $\begin{array}{c}1 \\
(24 \cdot 2)\end{array}$ & $\begin{array}{c}3 \\
(4-13 \cdot 4)\end{array}$ & 5 \\
\hline Total & 17 & 2 & 8 & 8 & 15 & 50 \\
\hline
\end{tabular}

*See Table II for key to dosage groups.

†Numbers in parentheses represent total dosage of DRB in $\mathrm{mg} / \mathrm{kg}$ body weight.

TABLE IV

Results in Relation to Type and Stage of Leukaemia (42 cases-Groups II-IV)

\begin{tabular}{|c|c|c|c|c|c|}
\hline & $\begin{array}{l}\text { Complete } \\
\text { Remission }\end{array}$ & $\begin{array}{l}\text { Bone Marrow } \\
\text { Remission }\end{array}$ & $\begin{array}{c}\text { Clinical } \\
\text { Remission }\end{array}$ & $\begin{array}{c}\text { Partial } \\
\text { Remission }\end{array}$ & $\begin{array}{c}\text { No } \\
\text { Remission }\end{array}$ \\
\hline $\begin{array}{c}\text { Acute lymphoblastic } \\
\text { New cases (27 cas } \\
\text { Group II (5) } \\
\text { Group III (20) } \\
\text { Group IV (2) } \\
\text { Treated cases (13 } \\
\text { Group II (5) } \\
\text { Group III (8) }\end{array}$ & $\begin{array}{r}1 \\
13 \\
0 \\
\\
0 \\
2\end{array}$ & $\begin{array}{l}0 \\
1 \\
0 \\
0 \\
1\end{array}$ & $\begin{array}{l}3 \\
3 \\
1 \\
0 \\
0\end{array}$ & $\begin{array}{l}0 \\
3 \\
1 \\
2 \\
0\end{array}$ & $\begin{array}{l}1 \\
0 \\
0 \\
3 \\
5\end{array}$ \\
\hline $\begin{array}{l}\text { Acute myeloid leukae } \\
\text { New cases } \\
\text { Group II (1) } \\
\text { Group III (1) }\end{array}$ & $\begin{array}{l}0 \\
0\end{array}$ & $\begin{array}{l}0 \\
0\end{array}$ & $\begin{array}{l}0 \\
0\end{array}$ & $\begin{array}{l}1 \\
0\end{array}$ & $\begin{array}{l}0 \\
1\end{array}$ \\
\hline Total & 16 & 2 & 7 & 7 & 10 \\
\hline
\end{tabular}

and $\mathrm{V}$ have not been included in that table because their regimens differed fundamentally from each other and from those in Groups II, III, and IV.

Criteria of response. The criteria for complete remission were defined as disappearance of all symptoms and signs of the leukaemia (e.g. anorexia, fever, bleeding, splenomegaly, lymphadenomegaly), with return of the bone marrow to normal and of the peripheral blood picture to near normal, i.e. at least $11 \mathrm{~g} \mathrm{Hb} / 100 \mathrm{ml}, 1500$ neutrophils $/ \mathrm{mm}^{3}$, and 120,000 platelets $/ \mathrm{mm}^{3}$.

Bone marrow remission was defined as return to a normal proportion of blast cells in the bone marrow, i.e. the blast cells numbered not more than 5\%, and the blast cells plus lymphocytes in lympho- blastic leukaemia numbered not more than $40 \%$ of the total nucleated cells, in the presence of clinical signs of the disease.

Clinical remission was defined as a complete remission as described above except that no examination was done to establish that the bone marrow had returned to normal.

Partial remission was defined as improvement in the symptoms, signs, peripheral blood, and bone marrow findings short of that which qualified as a complete remission as defined above.

In both complete remission and clinical remission the improvement was maintained for at least one month during which either DRB or another drug such as 6-mercaptopurine was continued as maintenance therapy. 
Analysis. Each of the first 3 types of remission -complete, bone marrow, and clinical-can reasonably be regarded as a good response. Table III shows that such remissions occurred in 20 out of 29 cases $(69 \%)$ on the Group III regimen. Good responses were somewhat less frequent in the other 4 groups, but the smaller numbers in these do not permit a valid conclusion that the Group III regimen is superior. This table also indicates the wide range in the total dosage of DRB given, with some children obtaining a good response to a small total dose while others failed to remit with a relatively large one.

Significant results were obtained in relation to the type and stage of the leukaemia, as shown in Table IV. A good response was obtained in 25 of 40 cases $(62.5 \%)$ of acute lymphoblastic leukaemia but in neither of the 2 cases of acute myeloid leukaemia. 'New cases' of acute leukaemia (including both types) obtained a good response in 22 of $29(76 \%)$; previously treated cases did so in only 3 of 13 cases $(23 \%)$. 'New cases' of acute lymphoblastic leukaemia did even better; there was a good response in 22 of 27 cases $(81 \%)$ and either a complete or at least a bone marrow remission in $15(56 \%)$.

In the 3 cases in Group I, in which the regimen was one of daily injections for courses of 3 to 5 days, there was one clinical remission, in a previously treated child with acute lymphoblastic leukaemia. No remission occurred in either of the 2 other cases. In the 5 cases in Group V, there was one complete remission in a new case of acute lymphoblastic leukaemia and one good partial remission in a new case of acute myeloid leukaemia. No remission occurred in 2 new cases of acute myeloid and one treated case of acute lymphoblastic leukaemia, but 2 of these received only $4-7 \mathrm{mg} / \mathrm{kg}$ of DRB before they died.

\section{Side-effects}

In each case the urine was coloured red for 6 to 8 hours after each injection of DRB. In some, this was the only side-effect. Occasionally a localized non-suppurative phlebitis or cellulitis occurred at the site of the injection, presumably due to extravascular injection or leakage.

The incidence and frequency of all the side-effects that were probably or possibly attributable to DRB are presented in Table V. Neutropenia $(<1500$ neutrophils $\left./ \mathrm{mm}^{3}\right)$, thrombocytopenia $(<100,000$ platelets $\left./ \mathrm{mm}^{3}\right)$, and anaemia $(<10 \mathrm{~g} \mathrm{Hb} / 100 \mathrm{ml})$ occurred frequently. They were of course often present at the onset of treatment. If, after the first injection of DRB, further cytopenia occurred

\section{TABLE V}

Incidence and Frequency of Complications with Daunorubicin Possibly due to Drug Toxicity

\begin{tabular}{l|rrr}
\hline Neutropenia & \multicolumn{3}{|c}{46 cases $(92 \%)$} \\
Anaemia & 41,9 & $(82 \%)$ \\
Thrombocytopenia & 38 & $(76 \%)$ \\
Haemorrhage & 10, & $(20 \%)$ \\
Infection & & & \\
$\quad$ Stomatitis & 9 & $(18 \%)$ \\
$\quad$ Septicaemia & 6 & $(12 \%)$ \\
$\quad$ Other & 8 & $(16 \%)$ \\
Nausea, vomiting, and/or abdominal pain & 24 & $(48 \%)$ \\
Diarrhoea & 4 & $(8 \%)$ \\
Alopecia & 1 & $(2 \%)$ \\
Cardiotoxicity & 2 & $(4 \%)$ \\
\hline No. of cases & 50 & $(100 \%)$ \\
\hline
\end{tabular}

in the presence of signs of clinical improvement, this was recorded as a toxic side-effect, though it may in fact have been due to other causes. The neutropenia, which was usually at a level of less than 1,000 neutrophils $/ \mathrm{mm}^{3}$, reached its lowest point 10 to 14 days after the injection.

During the periods of most severe neutropenia (less than 200 neutrophils $/ \mathrm{mm}^{3}$ ), 'reversed barrier nursing' was arranged in single rooms, and antibiotics against both Gram-positive and Gramnegative organisms were given prophylactically. The infections which did occur were chiefly stomatitis and septicaemia. The organisms isolated on blood culture were Gram-negative bacilli in 3 cases (pseudomonas, klebsiella species, and unidentified), and Gram-positive cocci in 2 ( $\alpha$-haemolytic streptococcus and Staphylococcus albus). Stomatitis due to candidiasis occurred in 6 cases. Other infections such as cellulitis of the face, otitis media, bronchitis, and generalized candidiasis were also seen. Most bacterial infections responded well to treatment with appropriate antibiotics.

When thrombocytopenia was severe (platelets $<60,000 / \mathrm{mm}^{3}$ ), children were given prednisolone up to $50 \mathrm{mg} / \mathrm{m}^{2}$ per day, sometimes with transfusions of platelet-rich plasma or, if anaemia was present, of fresh blood. Anaemia arising as a probable toxic side-effect required blood transfusion in only 11 cases; 8 of these had received doses of DRB greater than $2 \mathrm{mg} / \mathrm{kg}$, in combination with vincristine in one of them.

Gastrointestinal symptoms such as nausea, vomiting, abdominal pain, or diarrhoea occurred, but were never severe and their duration was limited to 24 to 48 hours after the injection.

Alopecia developed in one child with acute myeloid leukaemia who had received radiotherapy 
to the antrum and orbit 5 months before starting treatment with DRB.

Possible cardiotoxicity occurred in 2 children who had received DRB. One child developed tachycardia and cardiomegaly on radiological examination after a total dose of $25 \mathrm{mg} / \mathrm{kg}$. Though these signs proved reversible, necropsy 5 months later revealed some fragmentation of myocardial fibres. The second child was symptom free after a total dose of DRB of $12.5 \mathrm{mg} / \mathrm{kg}$, but necropsy 5 months later revealed similar fragmentation of myocardial fibres. This child had also received irradiation of the mediastinum 7 months before death.

Death occurred during DRB therapy in 9 cases; in all, it was attributable to infection or to haemorrhage in association with pancytopenia in the presence of extensive leukaemic infiltration.

\section{Discussion}

The development of new antineoplastic drugs has proceeded at an increasing pace in recent years and the total number available now approaches three figures. In this situation there is a danger that a drug may be discarded in favour of another before it has received a really adequate trial, in more than one dosage and more than one kind of regimen. DRB may possibly be in this position, for a potential successor to it (Adriamycin) is currently undergoing clinical trials though the optimum dosage and regimen for DRB have not as yet been determined.

In this study intermittent dosage of DRB resulted in the induction of remissions at least comparable with those obtained in other studies with daily injections, i.e. in our series (Table IV) $93 \%$ complete or partial remissions in previously untreated cases of acute leukaemia of either type, and 38\% complete or partial remissions in previously treated cases, compared with up to $100 \%$ complete or good partial remissions in previously treated cases, and $44 \%$ complete or good partial remissions in previously treated cases (Tan and Wollner, 1968). The interval between injections was usually 10 to 14 days and in 'new cases' (previously untreated), complete remission commonly occurred after only two or three injections.

Group I included 3 children on daily injections, all in a terminal stage and 2 of them receiving only limited dosage, and no conclusions can be drawn from them. The 5 children in Group $V$ all received their DRB as part of combination therapy with at least 2 other drugs, so the effect of DRB in them is not assessable. They illustrate the feasibility of combining DRB with other cytotoxic drugs; the indication for doing so was a need to induce remission with rapidity because the child was about to travel overseas or had advanced myeloid or terminal lymphoblastic leukaemia.

The 42 children in Groups II, III, and IV all received DRB on an intermittent basis with only minor differences in dosage between the groups and without other cytotoxic drugs being given concurrently. Group III became the largest of the five because of early indications that its regimen was proving the most satisfactory one to use.

In the total series of 50 children, remission of some degree occurred in $35(70 \%)$ and a good response in $27(54 \%)$. At least 4 of the poor responders, however, received no more than 2 injections, and though this much DRB with prednisolone did sometimes succeed in producing a good remission, 2 doses cannot be regarded as an adequate trial, particularly when the leukaemia is well advanced.

The most informative results come from analysing the findings in Groups II, III, and IV (Table IV). New cases of acute lymphoblastic leukaemia had a good response in 22 of $27(81 \%)$. This response rate is comparable with the best reported with any other drug combined with a corticosteroid.

Children previously treated with other drugs on which they had relapsed showed less response to DRB and prednisolone, as was anticipated. Nevertheless remissions did occur in 5 of a total of 13 treated cases of acute lymphoblastic leukaemia, and 2 of these were complete remissions. These children had been on other antileukaemic drugs for a median period of over 2 years before starting DRB, so even this limited response is deserving of note. With acute myeloid leukaemia only minimal evidence of response occurred.

These results of an intermittent regimen of DRB given every 7 to 14 days, with prednisolone initially, compare very favourably with those reported by other workers using courses of daily injections for 3 to 5 days. The advantage to young children of being able to achieve an adequate response with fewer injections needs no emphasis. Only 2 or 3 injections, with a total dose of $7 \mathrm{mg}$ DRB or less, were required to produce 10 of the 16 complete remissions recorded in Table IV. One of these children who had a complete remission after 2 injections of DRB plus prednisolone, and was maintained with 6-mercaptopurine until she relapsed 3 years later, had a complete remission reinduced recently, again with only 2 doses of DRB. A larger dose was given to children whose leukaemia had become resistant to all 4 regular drugs-6-mercaptopurine, cyclophosphamide, 
methotrexate, and vincristine; to those with acute myeloid leukaemia; and to those who failed to respond to smaller doses.

Early in this study an attempt was made to use DRB for maintenance therapy by continuing the injections after complete remission was established. One child with acute lymphoblastic leukaemia previously treated for 2 years with other drugs obtained a complete remission from 4 injections of DRB with prednisolone; he continued on DRB to a total dose of $24 \mathrm{mg} / \mathrm{kg}$ in 15 weeks. The risk of cardiotoxicity with higher doses, however, makes it inadvisable to use this drug for maintenance therapy.

Intermittent dosage with DRB in single injections of $2 \cdot 0-2 \cdot 5 \mathrm{mg} / \mathrm{kg}$ did not cause any more toxicity than has been reported with daily injections of 1 $\mathrm{mg} / \mathrm{kg}$. Cytopenia and the related hazards of infection and haemorrhage were the most serious side-effects, and were most severe when the injection of DRB was greater than $2 \mathrm{mg} / \mathrm{kg}$ or was given in combination with vincristine, 6-mercaptopurine, or cytosine arabinoside. However, full recovery from these side-effects occurred in all patients who obtained a complete remission.

At the same time as this study was in progress, 16 children with solid tumours were treated with DRB as part of their therapy. There were 9 cases of neuroblastoma, 6 of soft tissue sarcoma, and one of Ewing's tumour. Cytopenia was much less marked in this group, though the incidence of other side-effects resembled that found in the children with acute leukaemia. In the solid tumour group neutropenia occurred in $56 \%$ of cases compared with $92 \%$ of cases in the leukaemia group, anaemia in $44 \%$ compared with $82 \%$, thrombocytopenia in $25 \%$ compared with $76 \%$, and haemorrhage in $6 \%$ of cases in the tumour group, compared with $20 \%$ of cases in the leukaemia group.

Cardiotoxicity, which has been a major hazard in most trials in adults, was not a serious problem in this study. This is probably because the total dose of DRB did not exceed $26.8 \mathrm{mg} / \mathrm{kg}$ in any one child. The pathological changes in the myocardium found at necropsy in 2 cases could well have been due to another cause.

Although 9 of the 50 children died while receiving therapy including DRB, in no case was the death directly attributable to DRB. It is possible in 4 cases with extensive leukaemic infiltration that DRB-induced cytopenia contributed to the development of fatal septicaemia and/or haemorrhage.

We are indebted to the Senior Medical Staff of the Royal Children's Hospital for the referral of children for this study, to Dr. L. I. Taft and his staff for the investigations, to Miss Alison Crawn for assistance with records, and to Mr. K. C. Curnick of May \& Baker (Aust.) Pty. Ltd. for assistance in providing samples of daunorubicin.

\section{REFERENCES}

Bernard, J., Jacquillat, G., Boiron, M., Najean, Y., Seligmann, M., Tanzer, J., Weil, M., and Lortholary, P. (1967). Essai de traitement des leucémies aiguës lymphoblastiques et myéloblastiques par un antibiotique nouveau: la rubidomycine (13057 RP). Presse Médicale, 75, 951.

Bernard, J., Jacquillat, C., Weil, M., Boiron, M., and Tanzer, J. (1970). Present results on daunorubicine. In Advances in the Treatment of Acute (Blastic) Leukaemias (Recent Results in Cancer Research, 30), p. 3. Heinemann, London.

Hardisty, R. M., and Norman, P. M. (1967). Preliminary experience with rubidomycin in the treatment of acute lymphoblastic leukemia resistant to other antimetabolites. Pathologie et Biologie, 15, 941.

Holland, J. F. (1967). Daunomycin treatment in acute leukemia. Pathologie et Biologie, 15, 929.

Holland, J. F. (1968). Daunomycin and its place in chemotherapy of leukaemia. Convegni Farmitalia, Rio de Janeiro, p. 64.

Jacquillat, C., Tanzer, J., Boiron, M., Najean, Y., Weil, M., and Bernard, J. (1966). Rubidomycin, a new agent active in the treatment of acute lymphoblastic leukaemia. Lancet, 2, 27.

Macrez, C., Marneffe-Lebrequier, H., Ripault, J., Clauvel, J. P., Jacquillat, C., and Weil, M. (1967). Accidents cardiaques observés au cours des traitements par la rubidomycine. Pathologie et Biologie, 15, 949.

Tan, C., and Tasaka, H. (1966). Daunomycin remissions in acute leukemia. Proceedings of the American Association for Cancer Research, 7, 70.

Tan, C., Tasaka, H., Yu, K. P., Murphy, M. L., and Karnofsky, D. A. (1967). Daunomycin, and antitumor antibiotic, in the treatment of neoplastic disease. Cancer (Philadelphia), 20, 333.

Tan, C., and Wollner, N. (1968). Clinical facts of daunomycin in children with acute leukaemia and other neoplastic diseases. Convegni Farmitalia, Rio de Janiero, p. 42.

Correspondence to Dr. R. N. Matthews, Department of Haematology, Royal Children's Hospital, Flemington Road, Parkville, Victoria 3052, Australia. 